\begin{tabular}{|c|c|}
\hline \multirow{2}{*}{$\begin{array}{l}\text { DE GRUYTER } \\
\text { OPEN }\end{array}$} & ECONOMIC THEMES (2014) 52 (1): 81-98 \\
\hline & DOI 10.1515/ethemes-2014-0006 \\
\hline
\end{tabular}

\title{
RISK FACTOR MANAGEMENT: A MECHANISM OF SUPPORTING SUPPLY CHAIN RESILIENCE
}

\author{
Aleksandra Anđelković \\ University of Niš, Faculty of Economics, Serbia \\ $\square$ aleksandra.andjelkovic@eknfak.ni.ac.rs \\ Nada Barac \\ University of Niš, Faculty of Economics, Serbia \\ $\triangle$ nada.barac@eknfak.ni.ac.rs

\section{Goran Milovanović} \\ University of Niš, Faculty of Economics, Serbia \\ $\bowtie$ goran.milovanovic@eknfak.ni.ac.rs
}

UDC

005:330.131.7

658.7

Original

scientific

paper

Received:

18.10.2013

Accepted:

20.02.2014

\begin{abstract}
Supply chain assumes a unique business process without inter-company boundaries. Each supply chain partner is important for achievement of customer requirements. On the one hand, supply chain is an inexhaustible source of competitive advantage, created by the companies, which constitute it. However, on the other hand, due to its complexness, supply chain is an easy target of numerous factors, which jeopardize its competitiveness. Some of those factors are: turbulence, deliberate threats, external pressures, resource limits, sensitivity, and supplier/customer disruptions. Successful dealing with those factors assumes establishment of mechanisms for increasing supply chain resilience. Many researches indicate that some factors have greater influence on supply chain disruption and discontinuance. If those factors can be isolated, it will be easier to manage them or to avoid their influence. Therefore, the objective of the research presented in this paper is identification of the most frequent causes of supply chain disturbances, as a first step for developing supply chain resilience. According to the research results, the authors suggest what should be a primary focus of supply chain management, dealing with issues of resilience. Also, the authors indicate which characteristics (capability factors) supply chains have to have in order to be considered resistant.
\end{abstract}

Keywords: supply chain, competitive advantage, resilience, factors 


\section{Introduction}

Global supply chains give enormous competitive advantage to the companies which make them up. Small companies are not equipped to deal with serious global competition. Therefore, they use their membership in global supply chains to gain international presence and survival in complex international environment. Apart from this, there are numerous other reasons for joining a supply chain. Some of often quoted reasons (Donga; Glaister; 2006;580) are: outsourcing and transferring the production into a country with lower costs of production, maintaining the competitiveness; acquirement of raw materials or sourcing; easier access to knowledge offered by partners; easier exchange of complimentary technology ; securing the larger portion of market share; the split of costs of research and development between partners, faster investment return; faster and easier exchange of information; collaboration with potential partners, etc.

Frequent changes in the environment are the cause of increasing uncertainty in the market place. The importance of supply chain management is more pronounced at highly competitive markets. According to Ketchen and Hult, the situation of highly competitive markets could be described as rivalry among supply chains rather than individual firms (Kopecka, J., Penners, G., Santema, S., 2010, 513). This is the reason why the agility of supply chain becomes more and more important. The more uncertain and unpredictable the environment is, the supply chains are more vulnerable. Just-in-time manufacturing, increasing market requirements and shorter product life cycle caused a need for more resilient supply chain. Supply chain managers are increasingly concerned for managing a variety of risks. They aim to increase reliability of delivery and achievable value. For this purpose, analysis of business success factors can be very useful (Bošković, G.., Anđelković Pešić, M., Janković Milić, V., 2011).One of the basic principles of the construction of a resistant supply chain is to ensure a high level of collaboration among partners. Thus established relationships provide easier and faster ways to identify and manage risks in the supply chain. A high level of collaboration can contribute to the mitigation of risk or vulnerability and serve as a shock absorber. This can significantly aid the analysis of factors of business success. However, supply chain managers must be proactive. They must identify and take actions for elimination or mitigation of disturbances effect (Craighead, C., Blackhurst, B., Rungtusanatham, M. \& Handfield, R., 2007, 136).

The most important characteristics of supply chain resilience are flexibility, agility, velocity, and visibility. Some authors have given explanation for these characteristics. Sheffi explains flexibility like help to companies in correctly answering to markets' variability (Sheffi, Y., 2006, 13). He considers that flexibility can be achieved by using some strategies as concurrent processes, 
final goods completing postponement inside the supply chain, sharing with suppliers (Sheffi, Y., 2006, 13; Anđelković, M., 2003). Hewlett-Packard company is a good example. In this company, the assembly of parts in final product is delayed until the reception of requires coming from different markets.

The authors, Christopher and Rutherford in the paper "Creating a Resilient Supply Chains: A Practical Guide" give definition and description of the supply chain agility, velocity, and visibility (Longo, Ören, 2008, 528). According to these authors, agility is ability of a company to quickly respond to unforeseen and unpredictable demand/supply markets changes (Longo, Ören, 2008, 528). However, agility of a company depends on the agility of other supply chain participants. Supply chain velocity is an attribute which is explained as time required for moving goods along the supply chain. Sometimes, velocity is explained in terms of lead time. Visibility is compatibility of the company to see all information about the flow of products, information and finances in both directions (downstream and upstream along the supply chain).

\section{Supply Chain Risks}

Risk is a concept which we face in everything we do and cannot be easily defined. Risk is the result of a specific incident and the probability of its occurrence. The risk occurs due to inadequate or failed internal processes, people and systems or due to external events. A key component of risk is the lack of knowledge about the events that might affect the managers and their ability to manage these components.

Supply chains, due to the complex structure of interorganizational structures, are inherently subjected to risks. Thus, for several years, the risk of supply chain has been a favorite topic among researchers and managers of companies. Uncertainty contained in the supply chain has exogenous character of any of the stages, because the functioning of the chain depends not only on this, but also on other stages. Other members share specific goals and motives on the level of the supply chain with focal member, however, there might be other members who have their own goals and motives that may conflict with those of the chain as a whole (Hult, GTM , Ketchen , DJ, \& Arrfelt , 2007 1035-1052; Barac, Milovanović, 2006, 133). Varied nature of the supply chain, goals, motives and relationships in the supply chain catalyze many strategic initiatives in the chain. For example, this is the case with various forms of postponing of the execution of key activities of the supply chain which might lead to the reduction of uncertainty of the supply chain.

A large number of scientific papers are devoted to the events that caused the disruption of supply chains and negatively affected their partners. The literature on disruptions in the supply chain is expanding, but its implementation is poor 
due to their different levels of complexity. Snyder and Shen (2006, 1237-1248) have developed a simulation model for the comparison of several nets of supply chains. Their method presented a comparison of stochastic disturbances of supply and demand. They concluded that these disorders have different influence on the optimal design of the supply chain. Numerous articles that have proposed methods, guidelines and concepts of risk management, with the ultimate goal of creating supply chains that are able to confront unforeseen events, i.e. return to its original or desired state after the disturbance of their functioning (resilience) have been published. This prompted researchers and managers to focus on supply chain risk and managing the risks. The two most important reasons behind this: 1) an increase in the frequency and magnitude of catastrophic events such as natural disasters and 2) increase the vulnerability of modern supply chains.

However, it is still hard to help companies measure their own level of exposure to risk in the supply chain, and most importantly to manage these risks. Managers still do not have enough awareness of the business implications of risks in supply chains. In spite of prolific research of this topic, as mentioned beforehand, the managers of companies still do not use the guidelines and recommendations provided by these research papers to measure and manage risks in the supply chain. The reason for this is that the managers still do not possess adequate awareness about business implications of supply chain risks. Unfortunately, widely accepted terms of risks in the supply chains are not in use in scientific circles. Regardless of risk management in the supply chain has strategic importance and is a high priority in the management structure of companies/organizations.

Due to the global recession, companies need to pay more attention to implementing a strategy for effective supply chain management. Flexible strategies supply chain management can be the basis of its global competitiveness and survival. Serious disruptions / disturbances in the functioning of the supply chain can be caused by an increase in oil prices, protectionist measures of the government and rising costs.

The earthquake that struck Japan on March $11^{\text {th }}$ of 2011 and the current recession have increased the threat of the members of the supply chain. Interruptions of supply chains have left their mark on Japanese economy, as well as on business conducted by companies from other countries which were partners in global supply chains. Thus, effective implementation of strategies to reduce risk in the supply chain has become a priority target of companies around the world. Companies have realized that, regardless of the country and the industry, its competitiveness and profitability must be based on the redefined risk management strategies in their supply chains, as well as with the increase in the complexity of the supply chain and increasing their vulnerability values. 
Because of the negative impact on the outcome (final result), the term risk is almost exclusively placed in a negative context. The risk, in most cases, is the probability that in games of chance, one would get less desired outcome. For example, the risk of a speeding car is a speeding ticket, or worse, causing a traffic accident. Webster's Dictionary defines risk as „exposure to risk" (Webster, 1983). Some authors have dealt with quantifying different risk. Royal Society (Royal Society, 1992, 4) states the following definition of risk: „Risk is the chance, in quantitative terms, the emergence of defined danger." Norrman A. Jansson and U. risk expressed as follows:

$$
\begin{gathered}
\text { Risk }=\text { Probability }(\text { event }) \times \text { impact on business (weight, strength) } \\
\text { (Norrman, Jansson, 2004, 451). }
\end{gathered}
$$

They pointed out that the risks can be calculated, but the uncertainties remain fairly unknown. Irrespective of the nature, accuracy and applicability of the model and a formula for quantifying risk statement is that it is much easier to perceive the risks than to quantify them. This is caused by different definitions indicating the heterogeneity of the authors' views on the issue of defining risk. Some of the above-mentioned definitions are not relevant for the supply chain. Therefore, we will, based on the respective determination and goal of this paper, analyze approaches to defining the risk of supply chain below.

Jüttner and his associates defined the risk of supply chain as a „variation of the distribution of possible outcomes of the supply chain, their likelihood, and their subjective values (Jüttner, Peck, Christopher, 2003, 200). Harland, C., Brenchley, R., and H. Walker, for example, concluded that the risk of supply chain associated with "the potential to cause danger, damage, loss, injury, or other adverse consequences" (Harland, Benchley, Walker 2003, 52).

In the field of supply chain management, risk can be identified by two fundamentally distinct approaches: 1) the risk of such threats and opportunities, and 2) the risk solely as a threat. The first approach is in line with common practice in many areas of study such as business finance. There are fluctuations around the expected (mean) value of performance measures which are used as an indicator of risk. The risk is equal to the variance and the probability of covering the rise in stock prices (upside potential) and the probability of falling stock prices (downside potential). The financial risk associated with the probability that the realized return on investment differ from the expected return. Therefore, risk includes not only poor results, i.e., lower yields than expected (downside risk), but good results, i.e. higher yields than expected (upside risk). Upside risks can help the organization to achieve the desired goals, downside risks may inhibit the achievement of these goals. In Chinese, the risk is perceived as a mixture of danger (danger, crisis) and opportunity. 


\section{Figure 1 Symbols risk in Chinese}

\section{危機}

The first symbol means „danger" and the other „opportunity”.These symbols indicate the trade- offs facing each investor - between the higher returns that come with greater opportunity and risk, which must be submitted, which is a consequence of certain danger.

Given the impact of the recent disturbances in the supply chain, we find another approach to risk, as something that is exclusively associated with danger and what is perceived as negative, suits modern supply chains the best. In addition, companies which usually meet their objectives (e.g. revenue or production volume) are determined not so much by the maximum but rather by the expected value. Therefore, in this case the risk is understood as a negative deviation from the expected value of some performance measure, which leads to negative consequences for the focal company in the supply chain. Hence, the risk is equated with the harmful effects of disorders of the supply chain - the resulting damage or loss.

Reducing exposure to risk (or risk) may mean reducing the chances of success. Milton Friedman's famous phrase - „There is no free lunch” has a logical extension. Those who want greater rewards must be willing to expose themselves at greater risk. The link between reward and risk is most visible when making investment decisions. Stocks are riskier than bonds, but generate higher returns in the long term. The increase in exposure is integral part of the success. The success of the company depends on the crucial decisions of the scope and type of risk that should be taken. A company that decides to protect itself from the overall risk is not likely to safely generate good results to their owners. However, the company that does not recognize the type of risk may go up, because risk may yield more negative than positive effects.

Therefore, global supply chains which have realized the implications risk management might have on their business have improved their resilience. Strategies for the increase in resilience of supply chain are focused on the elimination of disturbances and mitigation of the disturbances.

\section{Understanding Supply Chain Resilience}

The concept of resilience is present in many different fields, not just in business and management. Resilience concept found its application in engineering, ecological sciences and organizational research, which provided a solid base for creating a conceptual framework for supply chain resilience 
(Eltantawy, 2011, 403). Definition of resilience in engineering field is one of the basic: "the tendency of a material to return to its original shape after the removal of a stress" (Pettit, Fiksel, Croxton, 2010, 4). This definition could be applied in the context of supply chain. Supply chain partners must learn everything about the reasons of disturbance and adapt to a new configuration.

The authors Ponomarov and Holcomb explains resilient supply chain like "ability to prepare for unexpected events, respond to disruptions, and recover from them by maintaining continuity of operations" (Ponomarov, S., Holcomb, M., 2009, 126). President and CEO of Adaptive Learning Systems Dean Becker says "More than education, more than experience, more than training, a person's level of resilience will determine who succeeds and who fails" (Coutu, 2002 , 47). Resilient supply chains have ability to resist at all disruptions and on that way provide its competitive advantage (Sheffi, 2005, 4). According to Cristopher Martin resilient supply chains are have ability to change quickly (Christopher, 2000, 38).

The best way for ensuring organization or whole supply chain in chaotic and uncertain future is development resilient leaders or organizations. Some definitions of supply chain resilience are shown in Table 1.

Table 1 Definitions of Resilience

\begin{tabular}{|l|l|c||}
\hline \multicolumn{1}{|c|}{ Source } & \multicolumn{1}{|c|}{ Definition } & \multicolumn{1}{|c|}{$\begin{array}{c}\text { Field of } \\
\text { study }\end{array}$} \\
\hline $\begin{array}{l}\text { Merriam- } \\
\text { Webster (2007) }\end{array}$ & $\begin{array}{l}\text { Capability of a body to recover its size and shape } \\
\text { after deformation }\end{array}$ & Engineering \\
\hline Folke (2004) & $\begin{array}{l}\text { Ability to rebound from a disturbance while } \\
\text { maintaining diversity, integrity and ecological } \\
\text { processes }\end{array}$ & Ecology \\
\hline Gorman (2005) & Ability to bounce back from adversity & Psychology \\
\hline Stoltz (2004) & $\begin{array}{l}\text { Ability to bounce back from adversity and move } \\
\text { forward stronger than ever }\end{array}$ & Leadership \\
\hline $\begin{array}{l}\text { Rice and } \\
\text { Caniato (2003) }\end{array}$ & $\begin{array}{l}\text { Ability to react to and unexpected disruption and } \\
\text { restore normal operations }\end{array}$ & Supply chain \\
\hline Sheffi (2005) & Containment of disruption and recovery from it & Supply chain \\
\hline $\begin{array}{l}\text { Christopher and } \\
\text { Peck (2004) }\end{array}$ & $\begin{array}{l}\text { Ability of a system to return to its original state or } \\
\text { move to a new, more desirable state after being } \\
\text { disturbed }\end{array}$ & Supply chain \\
\hline Fiksel (2006) & $\begin{array}{l}\text { Capacity for complex industrial systems to survive, } \\
\text { adopt and grow in the face of turbulent change }\end{array}$ & Supply chain \\
\hline \hline
\end{tabular}

Source: Pettit, T. (2008) Supply Chain Resilience: Development of a Conceptual Framework, an Assessment Tool and an Implementation Process, PhD thesis, The Ohio State University, p. 14. 
The cost of rising petrol and diesel fuel prices for road vehicle use in the United Kingdom coming up to fuel protests and it causes transportation disruptions 2000. The second reason for analyses supply chain resilience is the outbreak of the Foot and Mouth Disease in early 2001. These two situations that caused the first widespread study on supply chain resilience began in the United Kingdom. The basic conclusions of study explored at the UK's industrial level are: 1) supply chain vulnerability is an important business issue, 2) little research exists into supply chain vulnerability, 3) awareness of the subject is poor and 4) a methodology is needed for managing supply chain vulnerability (Peck, 2003). "Some of business innovations and trends have succeeded for reducing higher probability, profit-sapping risks, like (World Economic Forum):

- Lean supply chains, by design, lay bare the causes of frequent failures, forcing organizations to learn and design reliability into their processes;

- Globalization provides opportunities for diversification of supply;

- Specialized production and scale accelerate learning and the ironing-out of risks;

- IT-enabled visibility gives advance warning of problems and enables decentralized solutions."

These innovations in some cases can cause risks. For example, lean supply chains can cause delays in production due to bottlenecks and thus endanger the entire supply chain. Supply concentration and IT reliance cause disorder if critical nodes fail (World Economic Forum).

Christopher and Peck (Christopher, Peck, 2004, 13) developed framework of supply chain resilience. According to them the key elements for achieving resilient supply chain are the following:

1) Resilience can be built into a system in advance of a disruption (i.e. reengineering),

2) High level of collaboration is required to identify and manage risks,

3) Agility is essential to react quickly to unforeseen events and

4) The culture of risk management is a necessity.

Supply chain capabilities could be defined as: "attributes that enable an enterprise to anticipate and overcome disruptions." These capabilities are essential in modern conditions to ensure survival of the global supply chains and they represent source of competitive advantage to chains that have them. In this connection the resilience of the supply chain is a priority in the fight against disturbances from the environment.

Developing capabilities in order to overcome the supply chain's vulnerabilities requires the establishment of balance between investment and risk. Some of capabilities and vulnerability are shown in Table 2. 
Table 2 Vulnerability and Capability Factors

\begin{tabular}{|c|c|c|c|}
\hline \begin{tabular}{|c|} 
Vulnerability \\
Factor
\end{tabular} & Definition & $\begin{array}{l}\text { Capability } \\
\text { Factor }\end{array}$ & Definition \\
\hline Turbulence & $\begin{array}{l}\text { Environment characterized } \\
\text { by frequent changes in } \\
\text { external factors beyond } \\
\text { your control }\end{array}$ & $\begin{array}{l}\text { Flexibility } \\
\text { in sourcing }\end{array}$ & $\begin{array}{l}\text { Ability to quickly change } \\
\text { inputs or the mode of } \\
\text { receiving inputs }\end{array}$ \\
\hline $\begin{array}{l}\text { Deliberate } \\
\text { threats }\end{array}$ & $\begin{array}{l}\text { Intentional attacks aimed at } \\
\text { disrupting operations or } \\
\text { causing human or financial } \\
\text { harm }\end{array}$ & $\begin{array}{l}\text { Flexibility } \\
\text { in order } \\
\text { fulfilment }\end{array}$ & $\begin{array}{l}\text { Ability to quickly change } \\
\text { outputs or the mode of } \\
\text { delivering outputs }\end{array}$ \\
\hline $\begin{array}{l}\text { External } \\
\text { pressures }\end{array}$ & $\begin{array}{l}\text { Influences, not specifically } \\
\text { targeting the firm, that } \\
\text { create business constraints } \\
\text { or barriers }\end{array}$ & Capacity & $\begin{array}{l}\text { Availability of assets to } \\
\text { enable sustained production } \\
\text { levels }\end{array}$ \\
\hline $\begin{array}{l}\text { Resource } \\
\text { limits }\end{array}$ & $\begin{array}{l}\text { Constraints on output } \\
\text { based on availability of the } \\
\text { factors of production }\end{array}$ & Efficiency & $\begin{array}{l}\text { Capability to produce } \\
\text { outputs with minimum } \\
\text { resource requirements }\end{array}$ \\
\hline Sensitivity & $\begin{array}{l}\text { Importance of carefully } \\
\text { controlled conditions for } \\
\text { product and process } \\
\text { Integrity }\end{array}$ & Visibility & $\begin{array}{l}\text { Knowledge of the status of } \\
\text { operating assets and the } \\
\text { environment }\end{array}$ \\
\hline Connectivity & $\begin{array}{l}\text { Degree of interdependence } \\
\text { and reliance on outside } \\
\text { entities }\end{array}$ & Adaptability & $\begin{array}{l}\text { Ability to modify operations } \\
\text { in response to challenges or } \\
\text { opportunities }\end{array}$ \\
\hline $\begin{array}{l}\text { Supplier/ } \\
\text { Customer } \\
\text { disruptions } \\
\end{array}$ & $\begin{array}{l}\text { Susceptibility of suppliers } \\
\text { and customers to external } \\
\text { forces or disruptions }\end{array}$ & Anticipation & $\begin{array}{l}\text { Ability to discern potential } \\
\text { future events or situations }\end{array}$ \\
\hline
\end{tabular}

Source: Pettit, T. (2008) Supply Chain Resilience: Development of a Conceptual Framework, an Assessment Tool and an Implementation Process, PhD thesis, The Ohio State University, pp. 26-28.

Figure 1 Measurement of Resilience



Source: Pettit, T. (2008) 
Linkages exist between each vulnerability factor and a specific set of capabilities that can directly improve balanced resilience (Pettit, Fiksel, Croxton, 2010, 4). Essence of resilience is presented in Figure 1. Supply chain resilience increases as capabilities increase and vulnerabilities decrease. Supply chains with great resilience have ability to gain advantage from disruptions (Sheffi, 2005, 1).

In situation when supply chain cannot develop capabilities to offset high levels of vulnerabilities they will be overly exposed to risks. In case that supply chain may over-invest in capabilities relative to its vulnerabilities and therefore erode profits. The best solution for supply chain is when capabilities and vulnerabilities are more balanced. A great number of authors define this as "balanced resilience".

Figure 2 Resilience Fitness Space

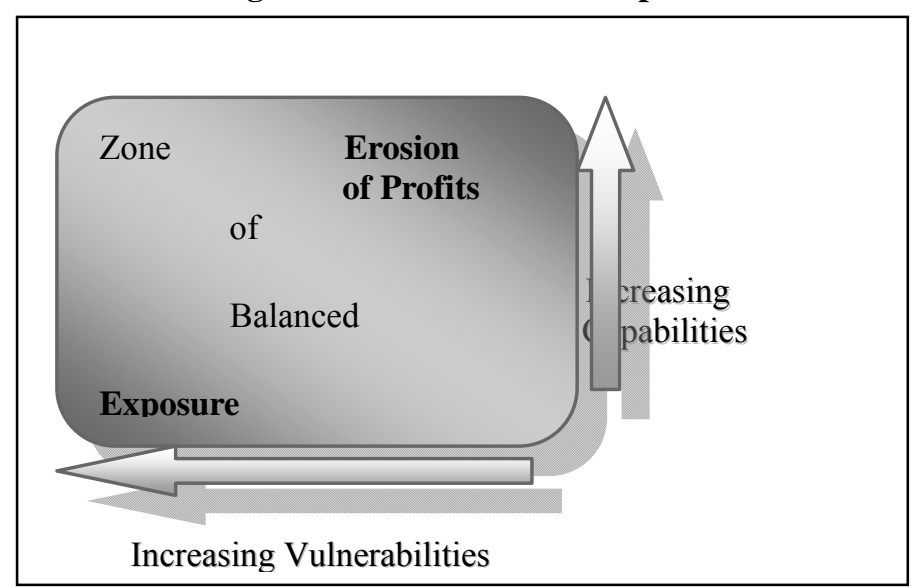

Source: Pettit, T. (2008)

\section{Levels of Uncertainty}

Supply chain vulnerabilities are a result of many drivers of risk. Great exposure to a number of risk drivers' influence reducing resilience of the entire supply chain. Disturbances could seriously threaten flows of operation in supply chain (Zsidisin, G., Panelli, A., Upon, R, 2000, 189). If supply chain have ability to overcame or adapt disturbances, the confidence in supply chain will be greater (Holcomb, M., Ponomarov, S., Manrodt, K., 2011, 40). In this sense, each supply chain must continuously increase resilience or improve competences which increase resilience of the whole supply chain. All drivers of risk could be defined at four levels (Peck, 2003, 15):

- Level 1 - Process/Value Stream,

- Level 2 - Assets and Infrastructure Dependencies, 
- Level 3 - Organisations and inter-organisational networks and

- Level 4 - The Environment

Level 1 - The supply chain could be described as "pipeline" flowing through and between companies in the network (see Figure 3). The aim of this complex structure is to provide efficient, value-based, management of individual flows of material/products, information and finance. "Supply chains carry one or more of these Value Streams" (Peck, H. 2003, 16). Credible and reliable information flow depends on the willingness of supply chain partners to share that information. High level of trust, coordination and collaboration are some of the conditions to achieve the information flow between partners. At this level risks, supply chain is affected by risks which coming from poor quality, demand volatility, changeable requirements of marketplace.

Figure 3 Partners of Supply Chain

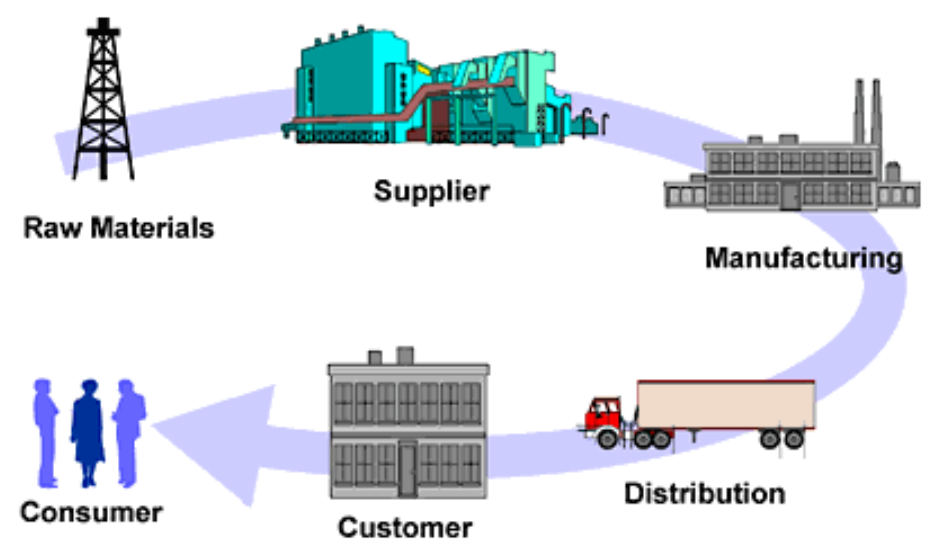

Source: PE-Energy (http://pe-energy.com/the-oilrig-supply-chain/)

The entire supply chain is composed of fixed points or facilities (e.g. factories, distribution centres, retails). The functioning of these points needs adequate IT assets (hardware, processing, and communications/service centres), which are in some way internal and inter-organisational communications networks. Networking fixed points in the supply chain system needs adequate national and international communications infrastructure and transportation/ distribution infrastructure.

Inadequate assets and infrastructure could cause disruptions of supply chain. Using assets and infrastructure for exchange information or business process could result in increase of the level of supply chain resilience.

Networking through supply chain is not based just on the adequate assets and infrastructure, but also on the relationships between the partners. 
Inadequate relationships and lack of trust among partners is one of the most common factors that cause interruptions and disruptions in the supply chain. Nevertheless, one of the most important principles of supply chain concept is that powerful partners do not abuse their position. Relations based on trust are necessary condition of development of resilient supply chain.

In some cases supply chain managers may work to achieve other commercial interests through competitive pressures and divergent strategic goals. This situation is one that causes increasing of supply chain vulnerability.

The fourth level of uncertainty in supply chain proceeds from external environment of supply chain. Factors which effect supply chain from external environment are political, economic, social, and technological. The sources of risks at this level are likely to be beyond the direct control of supply chain managers, nevertheless the vulnerability of supply chain can often be assessed in advance.

\section{Vulnerability and Capability Factors: The Research Results}

Bearing in mind that mentioned capability factors should make supply chain less vulnerable and therefore more resilient one can wonder whether there is connection between those two groups of factors. In order to make at least certain indication about this connection in the enterprises that do business in Serbia and to answer defined research question, the research has been conducted.

The research included 27 enterprises. All of the enterprises that were included into this research belong to certain supply chains, since the condition for an enterprise to be involved into the research was exactly its belonging to a supply chain. Hypotheses of the research concerns vulnerability and capability factors and connection between them. They are formulated as follows:

H1: Influence of vulnerability factors on supply chain functioning is strong.

H2: Usage of capability factors for facilitating supply chain functioning is high.

H3: Capability factors usage depends on vulnerability factors strength.

The following table shows results of descriptive statistics for vulnerability factors. According to the results vulnerability factors that have the greatest strength are Supplier/Customer disruptions (4.2593) and Turbulence (4.2222). On the other side, the least "problematic" vulnerability factor is Sensitivity (3.1111) and Resource limits (3.2222). Since the most of those factors are evaluated (in average) with relatively high marks, it may be indicated that influence of vulnerability factors on supply chain functioning is strong. 
Table 3 Descriptive Statistics for Vulnerability Factors

\begin{tabular}{|l|r|r|r|r|r||}
\hline & \multicolumn{1}{|c|}{$\mathrm{N}$} & Minimum & Maximum & Mean & $\begin{array}{c}\text { Std. } \\
\text { Deviation }\end{array}$ \\
\hline Turbulence & 27 & 2.00 & 5.00 & 4.2222 & .84732 \\
\hline Deliberate threats & 27 & 1.00 & 5.00 & 3.5185 & 1.45100 \\
\hline External Pressures & 27 & 1.00 & 5.00 & 3.5926 & 1.42125 \\
\hline Resource limits & 27 & 1.00 & 5.00 & 3.2222 & 1.31071 \\
\hline Sensitivity & 27 & 1.00 & 5.00 & 3.1111 & 1.33973 \\
\hline Connectivity & 27 & 1.00 & 5.00 & 3.2963 & 1.17063 \\
\hline SuppCustDisruptions & 27 & 1.00 & 5.00 & 4.2593 & 1.16330 \\
\hline
\end{tabular}

As opposed to results for vulnerability factors, results for capability factors show that the enterprises in the sample do not use appropriately and sufficiently possibilities for responding to vulnerability factors. This conclusion proceeds from data about mean for this sample. Precisely, two mostly used capability factors are Anticipation (3.6667) and Adaptability (3.1481). On the other side, the least used capability factors are Order fulfilment flexibility (1.1852) and Efficiency (1.5556). Shown results indicate that usage of capability factors for facilitating supply chain functioning is low.

Table 4 Descriptive Statistics for Capability Factors

\begin{tabular}{|l|r|r|r|r|r|}
\hline & $\mathrm{N}$ & Minimum & Maximum & \multicolumn{1}{c|}{ Mean } & \multicolumn{1}{c|}{$\begin{array}{c}\text { Std. } \\
\text { Deviation }\end{array}$} \\
\hline $\begin{array}{l}\text { Sourcing } \\
\text { Flexibility }\end{array}$ & 27 & 1.00 & 4.00 & 1.7778 & .75107 \\
\hline OrderFulFlexibility & 27 & 1.00 & 2.00 & 1.1852 & .39585 \\
\hline Capacity & 27 & 1.00 & 4.00 & 1.7037 & 1.17063 \\
\hline Efficiency & 27 & 1.00 & 3.00 & 1.5556 & .89156 \\
\hline Visibility & 27 & 1.00 & 4.00 & 1.7407 & 1.28879 \\
\hline Adaptability & 27 & 1.00 & 5.00 & 3.1481 & .98854 \\
\hline Anticipation & 27 & 1.00 & 5.00 & 3.6667 & 1.27098 \\
\hline
\end{tabular}

Beside results of descriptive statistics, another unsatisfactory thing is that those capability factors are not used together or not integrated, which additionally diminishes their influence on supply chain resilience. Correlation analysis results indicate that mentioned capability factors are not significantly correlated. Table 5 shows precise results of correlation analysis.

The results of correlation analysis show that correlation coefficient is quite low for the most of combinations (in the most of cases correlation coefficient is 
lower than 0.200). However, there are few coefficients that indicate correlation between capability factors (higher than 0.500) like correlation between Order fulfilment flexibility and Visibility (0.561) and Order fulfilment flexibility and Efficiency (0.553). On the other hand, some coefficients indicate inverse connection between capability factors (they have negative values). In certain cases this coefficient is very high, like for Adaptability and Efficiency, where correlation coefficient is -0.402 .

Table 5 Correlation Between Capability Factors

\begin{tabular}{|c|c|c|c|c|c|c|c|c|}
\hline & & $\mathrm{SF}$ & OFF & $\mathrm{C}$ & $\mathrm{E}$ & V & Ad & A \\
\hline \multirow{4}{*}{$\begin{array}{l}\text { Sourcing } \\
\text { Flexibility } \\
(\mathrm{SF})\end{array}$} & Correlation & & & & & & & \\
\hline & Coefficient & 1.000 & -.143 & -.217 & .340 & .132 & .006 & .012 \\
\hline & Sig. (2-tailed) & . & .477 & .276 & .083 & .511 & .976 & .951 \\
\hline & $\mathrm{N}$ & 27 & 27 & 27 & 27 & 27 & 27 & 27 \\
\hline \multirow{4}{*}{$\begin{array}{c}\text { Order Ful. } \\
\text { Flexibility } \\
(\mathrm{OFF})\end{array}$} & Correlation & & & & & & & \\
\hline & Coefficient & -.143 & 1.000 & .061 & $.553(* *)$ & $.561(* *)$ & -.199 & .184 \\
\hline & Sig. (2-tailed) & .477 &. & .763 & .003 & .002 & .321 & .359 \\
\hline & $\mathrm{N}$ & 27 & 27 & 27 & 27 & 27 & 27 & 27 \\
\hline \multirow[t]{3}{*}{$\begin{array}{c}\text { Capacity } \\
\text { (C) }\end{array}$} & $\begin{array}{l}\text { Correlation } \\
\text { Coefficient }\end{array}$ & -.217 & .061 & 1.000 & .069 & .174 & -.012 & .101 \\
\hline & Sig. (2-tailed) & .276 & .763 & . & .734 & .386 & .951 & .617 \\
\hline & $\mathrm{N}$ & 27 & 27 & 27 & 27 & 27 & 27 & 27 \\
\hline \multirow[t]{3}{*}{$\begin{array}{c}\text { Efficiency } \\
(\mathrm{E})\end{array}$} & $\begin{array}{l}\text { Correlation } \\
\text { Coefficient }\end{array}$ & .340 & $.553(* *)$ & .069 & 1.000 & $.407(*)$ & $-.402(*)$ & .136 \\
\hline & Sig. (2-tailed) & .083 & .003 & .734 & . & .035 & .038 & .500 \\
\hline & $\mathrm{N}$ & 27 & 27 & 27 & 27 & 27 & 27 & 27 \\
\hline \multirow[t]{3}{*}{$\begin{array}{c}\text { Visibility } \\
\text { (V) }\end{array}$} & $\begin{array}{l}\text { Correlation } \\
\text { Coefficient }\end{array}$ & .132 & $\begin{array}{r}.561\left(^{* *}\right. \\
) \\
\end{array}$ & .174 & $.407(*)$ & 1.000 & -.212 & .113 \\
\hline & Sig. (2-tailed) & .511 & .002 & .386 & .035 & . & .288 & .575 \\
\hline & $\mathrm{N}$ & 27 & 27 & 27 & 27 & 27 & 27 & 27 \\
\hline \multirow[t]{3}{*}{$\begin{array}{c}\text { Adaptability } \\
\text { (Ad) }\end{array}$} & $\begin{array}{l}\text { Correlation } \\
\text { Coefficient }\end{array}$ & .006 & -.199 & -.012 & $-.402(*)$ & -.212 & 1.000 & .329 \\
\hline & Sig. (2-tailed) & .976 & .321 & .951 & .038 & .288 & & .093 \\
\hline & $\mathrm{N}$ & 27 & 27 & 27 & 27 & 27 & 27 & 27 \\
\hline \multirow[t]{3}{*}{$\begin{array}{c}\text { Anticipation } \\
\text { (A) }\end{array}$} & $\begin{array}{l}\text { Correlation } \\
\text { Coefficient }\end{array}$ & .012 & .184 & .101 & .136 & .113 & .329 & 1.000 \\
\hline & Sig. (2-tailed) & .951 & .359 & .617 & .500 & .575 & .093 & \\
\hline & $\mathrm{N}$ & 27 & 27 & 27 & 27 & 27 & 27 & 27 \\
\hline
\end{tabular}

** Correlation is significant at the 0.01 level (2-tailed).

* Correlation is significant at the 0.05 level (2-tailed). 
Finally, research question included connection or dependability between vulnerability and capability factors. In order to portray the situation concerning connection between vulnerability factors and capability factors regression analysis has been applied. In this case, vulnerability factors are observed as independent variables, and capability factors as dependent variables.

Significance determined through regression analysis shows that capability factors depend on vulnerability factors (significance for all seven combinations is lower than 0.05). Capability factors usage depends on vulnerability factors strength. Connection of this result with the result concerning descriptive statistics it may be said that enterprises in the sample react to vulnerability factors, but unfortunately they do not do that appropriately or sufficiently. Also, bearing in mind low levels of connectivity between capability factors (the results of correlation analysis) it may be said that one of the reasons for inappropriate usage of capability factors is exactly disconnection between capability factors. If those factors are used parallel or if they are integrated the results might be different. This is one of the research questions for deeper, future research.

\section{Conclusion:}

\section{Recommendations to Build a More Resilient Supply Chain}

Many authors dealt with this problem and tried to devise ways for increasing the resilience of supply chains. Based on the research and analysis authors are provided some of the recommendations that could be used in the process of increasing resilience (Pochard, S., 2003, 67):

- Build a Risk Awareness Culture,

- Find a trade-off between recent practices such as Lean Manufacturing or JIT and Risk Management,

- Revisit single sourcing strategies,

- Introduce flexibility to enhance resilience,

- Quantifying the rewards of risk management can help to justify risk management investments.

Build a Risk Awareness Culture - Supply chain managers and all employees must be aware that supply chain is exposed to risks. All employees must have appropriate role in the risk management process. This should lead to organizational changes and the risk aware supply chain design (Pochard, S., 2003,68 ). Supply chain risk management is not the first priority of a firm but it is one of the most important part of supply chain management.

Find a trade-off between recent practices such as Lean Manufacturing or JIT and Risk Management - With implementation of Just-in-Time strategy and Lean manufacturing companies in supply chain have tried to eliminate all 
the wastes in supply chain, and focus on cost reduction. However, apart positive results of implementation of these strategies, there are consequences expressed as an increase in supply chain vulnerability. Therefore, companies in supply chain should create a balance between these strategies and supply chain risk management. Companies must consider some of the alternatives: single vs. multiple sourcing, zero stock vs. safety stock, and centralization vs. dispersion.

Revisit single sourcing strategies - Positive effects of single sourcing are cost-effectiveness, higher quality, relationship based on trust and implementation of the same business philosophy and methodology (Bošković, G.., Anđelković Pešić, M., 2011). When supplier goes out of business or produce lower quality product that can cause greater exposure of supply chain to risk this becomes a great problem. For solving this problem there are two solutions:

- Development of strong relationship with supplier and continuously monitoring the health of the concerning supplier (Anđelković Pešić, M., 2010),

- Partner in supply chain can consider more flexible strategies and contract with back-up suppliers. This involves signing long-term contracts, option contracts with various suppliers, creating a local supply source or creating multiple supply sources.

Introduce flexibility to enhance resilience - Flexibility of supply chain is its ability to respond to numerous changes in the environment. Companies in flexible supply chain can use availability of resources and take corrective actions to minimize the impact of unexpected disruptions. Therefore, companies have to build organisation and operating links through supply chain which facilitate a rapid changeover when needed.

Quantifying the rewards of risk management can help to justify risk management investments - Positive results of implementation of Just-in-Time strategy reflect in important savings. Supply chain risk management also has important benefits. Those benefits are reflected in the avoidance of big losses, but the quantification is not as obvious as for Just-in-Time implementation. Managers usually are focused on costs and are tempted not to undertake any measure of risk management.

Disturbances in supply chain have cascade effect because a huge dependencies between partners in supply chain (Svensson, 2004, 732). Each disturbance may cause negative effects not only to individual partners but also to whole supply chain (Barroso, A. P., Machado V. H., Cruz Machado V., 2011, 164). This is the reason because one of the key challenges of global supply chains in modern conditions is high level of resilience. 


\section{References}

Anđelković Pešić, M. (2010) Six Sigma metodologija za unapređenje procesa, Vrnjačka Banja: Scientific and Technical Center for Intellectual Property - SaTCIP.

Anđelković, M. (2003) Smanjenje troškova putem saradnje sa dobavljačima, Ekonomske teme, 41 (2): 409-414.

Barac, N., Milovanović G. (2006) Strategijski menadžment logistike, Niš: SKC Niš.

Barroso, A. P., Machado V. H., Cruz Machado V. (2011) Supply Chain Resilience Using the Mapping Approach, Supply Chain Management, (ed, Pengzhong Li), InTech, 161-184.

Bošković G., Anđelković Pešić M. (2011) Upravljanje kvalitetom - osnova konkurentnosti preduzeća i privrede, Niš: Ekonomski fakultet.

Bošković, G., Anđelković Pešić, M., Janković Milić, V. (2011) Cluster Analysis of Business Quality Factors In Serbian Economy, Collection of papers from: XVI International scientific conference problems of competitiveness of contemporary economies, Nis: Faculty of Econimics, 45-54.

Christopher, M. (2000) The Agile Supply Chain: Competing in Volatile Markets, Industrial Marketing Management, 29 (1): 37 - 44.

Christopher, M., Peck, H. (2004) Building the Resilient Supply Chain, International Journal of Logistics Management, 15 (2): 1-30.

Coutu, D. (2002) How resilience works, Harvard Business Review, 80 (5): 46-51.

Craighead, C., Blackhurst, B., Rungtusanatham, M. \& Handfield, R. (2007) The severity of supply chain disruptions: design characteristics and mitigation capabilities, Decision Sciences, 38 (1): 131-156.

Donga, G.(2006) Motives and Partner Selection Criteria in International Strategic Alliances: Perspectives of Chinese Firms, International Business Review, 15: 577-600.

Eltantawy, R. (2011) Supply Management Governance Role in Supply Chain Risk Management and Sustainability, Supply Chain Management - New Perspectives (ed, Sanda Renko), InTech, pp, 401-416.

Harland, Brenchley, Walker, (2003) Risk in supply network, Journal of Purchasing Supply Chain Management, 9(2): 51-62,

Holcomb, M., Ponomarov, S., Manrodt, K. (2011) The Relationship of Supply Chain Visibility to Firm Performance, An International Journal Supply Chain Forum, 12 (2): 32-45.

Hult, G. T. M., Ketchen, D. J., \& Arrfelt, M. (2007) Strategic supply chain management: Improving performance through a culture of competitiveness and knowledge management, Strategic Management Journal, 28(10).

Jüttner, Peck, Christopher, (2003) Supply chain risk management: Outlining an agenda for future research, International Journal of Logistics: Research and Applications 6 (4):197-210.

Kopecka, J., Penners, G., Santema, S. (2010) Flexibility in supply chain management, Operations Research, 53 (3): 512-524.

Longo, F, Ören, T. (2008) Supply chain vulnerability and resilience: a state of the art overview, Proceedings of European Modeling \& Simulation Symposium, 17-19 September 2008, Campora S, Giovanni (CS) Italy, pp, 527-533.

Norrman, Jansson. (2004) Ericsson' proactive supply chain risk management approach after a serious sub-supplier accident, International of Physical Distribution\& Logistics 34(5): 434-456.

Peck, H. (2003) Creating Resilient Supply Chains: A Practical, Guide, Cranfield University, Cranfield School of Management, UK. 
PE-Energ: http://pe-energy,com/the-oilrig-supply-chain/ (20.06.2013.)

Pettit, T., Fiksel, J., Croxton, K. L. (2010) Ensuring supply chain resilience: Development of a conceptual framework, Journal of Business Logistics, 31 (1): 1-21.

Pochard, S. (2003) Managing Risks of Supply-Chain Disruptions:Dual Sourcing as a Real Option, $\mathrm{PhD}$ thesis, Massachusetts Institute of Technology.

Ponomarov, S, Holcomb, M, (2009) Understanding the concept of supply chain resilience, The International Journal of Logistics Management, 20 (1): 124-143,

Royal Society, (1992) Risk Analysis, Perception and Management, London,

Sheffi, Y, (2005) Building a Resilient Supply Chain, Supply Chain Strategy - Harvard Business Review, 1 (8): 1-11.

Sheffi, Y. (2006) Resilience reduces risk, The Official Magazine of the Logistics Institute, 12 (1): 13-14.

Snyder, L. V., \& Shen, Z.J.M. (2006) Supply and demand uncertainty in multi-echelon supply chains, Working paper, P, C, Rossin College of Engineering and Applied Sciences, Lehigh University, Bethlehem, PA.

Svensson, G, (2004) Key areas, causes and contingency planning of corporate vulnerability in supply chains: A qualitative approach, International Journal of Physical Distribution \& Logistics Management, 34 (9): 728-742,

Webster, N. (1983) Webster's New Twentieth Century Dictionary, 2nd ed, Simon \& Schuster, New York.

World Economic Forum: http://www,accenture,com/SiteCollectionDocuments/ PDF/Accenture-Building-Resilience-Supply-Chains,pdf (12,03,2013,)

Zsidisin, G., Panelli, A., Upon, R. (2000) Purchasing organisation involvement in risk assessments, contingency plans, and risk management: an exploratory study, Supply Chain Management: An International Journal, 5 (4): 187-197.

\title{
UPRAVLJANJE FAKTORIMA RIZIKA: MEHANIZAM ZA POVEĆANJE OTPORNOSTI LANCA SNABDEVANJA
}

\begin{abstract}
Abstrakt: Lanac snabdevanja predstavlja jedinstven poslovni proces bez međukompanijskih granica. Svaki partner lanaca snabdevanja važan je za ostvarivanje zahteva korisnika. S jedne strane, lanac snabdevanja je neiscrpan izvor konkurentske prednosti, stvorene od strane kompanija koje ga čine. Međutim, s druge strane, zbog svoje kompleksnosti, lanac snabdevanja je laka meta brojnih faktora koji ugrožavaju njegovu konkurentnost. Neki od tih faktora su: turbulencije, namerne pretnje, spoljni pritisci, ograničenje resursa, osetljivost, poremećaji kod dobavljača/kupca. Uspešno upravljanje tim faktorima pretpostavlja uspostavljanje mehanizama za povećanje otpornosti lanca snabdevanja. Mnoga istraživanja pokazuju da neki faktori imaju veći uticaj na poremećaje i prekide u lancu snabdevanja. Ako se ovi faktori mogu izolovati, biće lakše upravljati njima ili izbeći njihov uticaj. Dakle, cilj istraživanja u ovom radu je identifikacija nekih najčešćih uzroka poremećaja u lancu snabdevanja, kao prvi korak za razvoj otpornih lanca snabdevanja. $\mathrm{Na}$ osnovu istraživanja, autori ukazuju na to šta bi trebalo da bude fokus menadžmenta lanca snabdevanja, koji se bavi pitanjem otpornosti. Takođe, autori ukazuju na karakteristike koje lanci snabdevanja moraju imati kako bi se smatrali otpornim.
\end{abstract}

Ključne reči: lanac snabdevanja, konkurentska prednost, otpornost, faktori 